Статівка Наталія Валеріївна доктор наук 3 державного управління, професор, завідувач кафедри управління персоналом та підприємництва Харківський національний університет імені В.Н. Каразіна, Навчально-науковий інститут "Інститут державного управління", вул. Маршала Рибалко, 51, кв. 13, м. Харків, 61099, тел.: (050) 043-38-50, e-mail: mbubliy@gmail.com, https://orcid.org/0000-0003-0903-6256

\title{
МЕТОДОЛОГІЧНІ ОСНОВИ ДЕРЖАВНОГО РЕГУЛЮВАННЯ МОНЕТАРНИХ ПРОЦЕСІВ В СУЧАСНІЙ ЕКОНОМІЦ
}

Анотація. У статті досліджено методологічні основи державного регулювання монетарних процесів в сучасній економіці. 3'ясовано, що державне регулювання монетарних процесів повинно проводитися на основі грошовокредитної і валютної політики (монетарної) та політики щодо забезпечення фінансової стабільності (макропруденційної), тому що. цілі, інструменти та процедури грошово-кредитного регулювання оформляються у вигляді монетарної політики, а регулювання фінансової стабільності - макропруденційної політики. Доведено, що такий підхід сформувався після світової фінансово-економічної кризи. Криза також призвела до того, що змінилися і методологічні засади державного регулювання монетарних процесів, а саме: цілі, об'єкти і суб'єкти, інструменти і трансмісійний механізм, а також правила.

Визначено, що в сучасній економіці підтримка стабільного рівня цін $\mathrm{i}$ забезпечення фінансової стабільності $\epsilon$ основними цілями державного регулювання монетарних процесів, які забезпечуються такими його елементами, як грошово-кредитне i валютне регулювання i регулювання фінансової стабільності. Об'єктами державного регулювання монетарних процесів $є$ попит на гроші та їх пропозиція, обсяг і структура грошової маси, що знаходиться в обігу; швидкість обігу грошей; обсяг кредитів, наданих економіці; коефіцієнти грошової мультиплікації; обсяг і структура грошових доходів та витрат учасників грошового обороту; курс національної грошової одиниці, коливання фінансових ринків, стабільність і взаємозв'язок учасників фінансових ринків. Суб'єктами державного регулювання монетарних процесів $\epsilon$ монетарна влада, в особі центральних банків та інших державних органів, що впливають на грошовокредитну і валютну сфери, а також органи, що регулюють фінансову стабільність. Інструменти грошово-кредитного та валютного регулювання застосовуються 3 метою забезпечення цінової стабільності. Однак, під інструментами, застосовуваними в державному регулюванні монетарних процесів, доцільно 
також розглядати інструменти, що застосовуються 3 метою забезпечення фінансової стабільності. Також доведено, що поєднання «політики за правилами» і «дискреційної політики» сприяє отриманню більшого ефекту від державного регулювання монетарних процесів 3 огляду на те, що дозволяє поєднувати грошово-кредитне регулювання і регулювання фінансової стабільності.

Ключові слова: державне регулювання, монетарні процеси, грошовокредитне регулювання, фінансова стабільність, цінова стабільність.

Stativka Nataliia Valeriivna Doctor of Public Administration, Professor, Head of Department of Personnel management and entrepreneurship, VN Kharkiv National University Karazina, Educational and Scientific Institute "Institute of Public Administration", Marshala Ribalko St., 51, apt. 13, Kharkiv, 61099, tel.: (050) 043-38-50, e-mail: mbubliy@gmail.com, https://orcid.org/0000-0003-0903-6256

\section{METHODOLOGICAL FOUNDATIONS OF STATE REGULATION OF MONETARY PROCESSES IN THE MODERN ECONOMY}

Abstract. The article examines the methodological foundations of state regulation of monetary processes in the modern economy. It was found out that state regulation of monetary processes should be carried out on the basis of monetary and monetary policy (monetary) and financial stability policy (macroprudential), because. the goals, instruments and procedures of monetary regulation are formed in the form of monetary policy, and the regulation of financial stability is formed in the form of macroprudential policy. It is proved that this approach was formed after the global financial and economic crisis. The crisis has also led to changes in the methodological foundations of state regulation of monetary processes, namely: goals, objects and subjects, tools and transmission mechanism, as well as rules.

It is determined that in the modern economy, maintaining a stable price level and ensuring financial stability are the main goals of state regulation of monetary processes, which are provided by such elements as monetary and currency regulation and regulation of financial stability. The objects of state regulation of monetary processes are the demand for money and its supply, the volume and structure of the money supply in circulation; the speed of money circulation; the volume of loans granted to the economy; monetary multiplication coefficients; volume and structure of monetary income and expenses of participants in money turnover; exchange rate of the national currency, fluctuations in financial markets, stability and interrelation of financial market participants. Subjects of state regulation of monetary processes are the monetary authorities, represented by central banks and other state bodies that influence the monetary and currency spheres, as well as bodies that regulate financial stability. Monetary and currency regulation instruments are used to ensure price stability. However, under the instruments used in the state regulation of monetary processes, it is also advisable to consider instruments used to ensure financial stability. It is also 
proved that the combination of "policy by rules" and "discretionary policy" contributes to obtaining a greater effect from state regulation of monetary processes due to the fact that it allows combining monetary regulation and regulation of financial stability.

Keywords: state regulation, monetary processes, monetary regulation, financial stability, price stability.

Постановка проблеми. У сучасному світі монетарні процеси мають значний вплив на стан і тенденції розвитку національної економіки будь-якої країни. У зв'язку 3 цим важливе значення має організація державного регулювання цих процесів, а також ефективно реалізовані грошово-кредитна, фінансова, валютна політики.

Разом 3 тим, що відбуваються в останні роки процеси в економіці та іi монетарній сфері доводять, що традиційні грошово-кредитна, фінансова та валютна політики не є достатньо ефективними в контексті досягнення фінансової стабільності та забезпечення економічного зростання. У зв'язку з цим, пошук основних напрямів модернізації державного регулювання монетарних процесів у сучасній економіці набуває особливої актуальності 3 наукової та практичної точок зору. Розробка цих напрямків передбачає проведення системного дослідження державного регулювання монетарних процесів, що включає аналіз питань досягнення не тільки цінової стабільності, але в цілому і стабільності всієї фінансової системи.

Аналіз останніх досліджень і публікацій. Дослідженню методологічної основи державного регулювання монетарних процесів в сучасній економіці присвячена низка публікацій. Серед них слід виділити праці таких вчених, Азарян О.М. [1], Башнянин Г.І. [7], Гончаров Ю.В. [10], Гудіма Т.С. [3], Єфименко T.I. [5], Ковтун О.I. [7], Куцик П.О. [7], Подік I.I. [10], Солійчук А.О. [2], Шепелев О. О. [1], Федишин М.П. [2] та ін. Разом з тим вивчення праць вітчизняних та зарубіжних авторів 3 питань державного регулювання монетарних процесів виявило, що до теперішнього часу недостатньо дослідженими залишаються питання змісту, методології та напрямків його розвитку, взаємозв'язку між регулюванням цінової та фінансової стабільності.

Метою статті $\epsilon$ узагальнення основних методологічних засад державного регулювання монетарних процесів та надання пропозицій з їх удосконалення.

Виклад основного матеріалу. 3 еволюцією монетарної сфери змінювалися i погляди на зміст процесів, що відбуваються в ній, відповідно, розвивалися погляди на зміст їх регулювання.

О. Азарян та О. Шепелев пропонують розуміти під державним регулюванням монетарних процесів комплексне поняття, що включає інституційно i законодавчо визначений порядок систематичного впливу регуляторів на фінансовий ринок, а в його структурі - на грошовий і кредитний ринки, їх суб'єкти та об'єкти, за допомогою використання інструментів, методів, 
трансмісійного механізму грошово-кредитного i фінансового регулювання для досягнення цілей розвитку національної економіки [1, с. 24].

На нашу думку у сучасній економіці під державним регулюванням монетарних процесів слід розуміти грошово-кредитне і валютне регулювання, а також регулювання фінансової стабільності центральними банками та іншими державними органами для досягнення і підтримки стабільного економічного зростання.

Розвиток уявлень про монетарні процеси та їх регулювання в свою чергу знайшло відображення в навчаннях різних наукових економічних шкіл.

Разом $з$ тим, на сучасному етапі розвитку суспільно-економічних відносин більшість вчених-економістів у регулюванні монетарних процесів враховують питання грошово-кредитної, валютної, а також фінансової сфери, у тому числі фінансову стабільність. Роль фінансової стабільності в регулюванні монетарних процесів розглядалася теоретиками ще в минулому столітті [1, с. 89], але тільки остання світова фінансово-економічна криза і рецесія звернули увагу більшості економістів до даного питання. Однак, хоча більшість економістів згодні з тим, що фінансова стабільність важлива в державному регулюванні монетарних процесів, думки ще розходяться на предмет того, як, якими засобами і методами iї враховувати.

Для дослідження даного питання проаналізуємо методологічні засади державного регулювання монетарних процесів.

Державне регулювання монетарних процесів в сучасній економіці, являє собою грошово-кредитне i валютне регулювання, a також регулювання фінансової стабільності центральними банками та іншими державними органами для досягнення і підтримки стабільного економічного зростання. Отже, державне регулювання монетарних процесів повинно проводитися на основі грошовокредитної і валютної політики (монетарної) i політики щодо забезпечення фінансової стабільності (макропруденційної), тому що. цілі, інструменти та процедури грошово-кредитного регулювання оформляються у вигляді монетарної політики [2, С. 12], а регулювання фінансової стабільності - макропруденційної політики. Такий підхід сформувався як результат світової фінансово-економічної кризи. Криза також призвела до того, що змінилися i методологічні засади державного регулювання монетарних процесів, а саме: цілі, об'єкти і суб'єкти, інструменти і трансмісійний механізм, а також правила.

Постановка мети $\epsilon$ найбільш важливим питанням, відправною точкою регулювання монетарних процесів і подальшого визначення об'єктів і суб'єктів, методів та інструментів, а також правил його здійснення. У той же час, мета регулювання монетарних процесів повинна відповідати меті регулювання національної економіки. Це обумовлено тим, що елементи державного регулювання монетарних процесів, а саме грошово-кредитне i валютне регулювання, а також регулювання фінансової стабільності є одними з механізмів державного регулювання економіки. Тому з одного боку, основною метою 
державного регулювання монетарних процесів, як частини регулювання національної економіки, має бути забезпечення добробуту громадян, що досягається зростанням економіки і підтриманням зайнятості. 3 іншого боку, нестабільність рівня цін, валютних i фінансових ринків, а також рівень процентних ставок безпосередньо впливають на динаміку економіки.

В якості цілей державного регулювання монетарних процесів, на наш погляд, слід розглядати цілі його елементів. Макроекономічна рівновага, тобто, досягнення і підтримання стабільно низького рівня цін, забезпечення високого рівня зайнятості, економічного зростання, стабільності валютних і фінансових ринків i рівноваги платіжного балансу визнаються цілями державного регулювання монетарних процесів, зокрема такого його елементу як грошовокредитне і валютне регулювання.

Серед вищеназваних цілей цінова стабільність розглядається монетарною владою як головна. Це пов'язано з тим, що, незважаючи на важливість досягнення кожної з цілей окремо, в короткостроковому періоді досягнення одних може привести до спотворення інших. Наприклад, високі темпи економічного зростання знижують безробіття, але це, в свою чергу, може супроводжуватися зростанням цін, якщо спостерігається інфляція попиту. 3 іншого боку, високий темп зростання цін знижує купівельну спроможність населення, сповільнюючи економічну активність. Крім того, при високому рівні інфляції монетарна влада може підвищити процентні ставки, як елемент антиінфляційної політики, що негативно позначається на економічному зростанні і зайнятості.

Таким чином, стабільність рівня цін, що визначається монетарною владою як стабільна і низька інфляція, розглядається в якості найбільш важливої мети грошово-кредитного i валютного регулювання. Однак стабільне економічне зростання також є однією з цілей грошово-кредитного і валютного регулювання, a спроби підтримувати інфляцію на одному рівні за всяку ціну, в короткостроковому періоді іноді можуть призвести до надмірних коливань економіки і зайнятості.

У зв'язку з цим існує інший підхід, згідно з яким не тільки цінова стабільність, а й підтримка максимальної зайнятості також є пріоритетною метою грошово-кредитного і валютного регулювання і пояснюється тим, що підтримка зайнятості безпосередньо впливає на добробут громадян, що є однією з основних цілей соціально-економічної політики держави, а в іiі структурі і монетарної політики. Крім того, при високих рівнях безробіття знижується виробництво матеріальних благ і послуг, що, згодом, призводить до спаду економіки. I як було вже згадано, підтримка інфляції на одному рівні за всяку ціну можуть призвести до надмірних коливань економіки, а, отже, і зайнятості.

Однак, слід зазначити, під підтриманням високого рівня зайнятості мається на увазі досягнення не нульового, а природного рівня безробіття, коли попит на ринку праці дорівнює пропозиції на ньому. Тому переслідуючи цілі забезпечення 
високої зайнятості, монетарна влада намагається підвищити продуктивність до потенційного рівня, який досягається при природному безробітті. Отже, теоретично, грошово-кредитне регулювання 3 двоїстим мандатом не сильно відрізняється від регулювання стабільності цінового рівня. Крім того, цілі цінової стабільності і зайнятості можна розглядати як взаємодоповнюючі, a не конкуруючі 3 огляду на те, що рівень зайнятості нижче при більш високій інфляції [3, с. 93].

Разом 3 тим, частина економістів вважають, що досягнення фінансової стабільності не відноситься безпосередньо до цілей грошово-кредитного i валютного регулювання. Прихильники даного підходу відзначають, що хоча забезпечення фінансової стабільності взаємопов'язане 3 цілями грошовокредитного і валютного регулювання, ефекти грошово-кредитного і валютного регулювання безпосередньо не призводять до фінансової стабільності [4, с. 31]. Аргументом служить той факт, що інструменти для досягнення цілей грошовокредитного i валютного регулювання i забезпечення фінансової стабільності розрізняються [4, с. 39]. Крім того, доводиться, що контрциклічне грошовокредитне i валютне регулювання в умовах фінансової стабільності дає макроекономічний ефект тільки при дуже низьких процентних ставках, а в інших обставинах реалізація такої політики призводить до зростання безробіття i зниження фінансової стабільності. Причому витрати суспільства від зростання безробіття виявляються вищими, ніж витрати, пов'язані з кризою. Т Сфименко, також дотримуючись даного підходу, стверджує, що збільшення процентних ставок для цілей фінансової стабільності, притягує іноземний капітал, тим самим породжуючи проблеми на валютному ринку [5, с. 65].

3 урахуванням огляду підходів до визначення цілей монетарної політики і вищенаведених причин слід розглядати як мету регулювання фінансової стабільності в структурі державного регулювання монетарних процесів, а не як мету грошово-кредитного і валютного регулювання. Отже, в сучасній економіці підтримка стабільного рівня цін і забезпечення фінансової стабільності $\epsilon$ основними цілями державного регулювання монетарних процесів, які забезпечуються такими його елементами, як грошово-кредитне i валютне регулювання і регулювання фінансової стабільності.

До настання світової фінансово-економічної кризи об'єктами державного регулювання монетарних процесів визнавалися попит на гроші та їх пропозиція, обсяг і структура грошової маси, що знаходиться в обігу; швидкість обігу грошей; обсяг кредитів, наданих економіці; коефіцієнти грошової (банківської) мультиплікації; обсяг i структура грошових доходів та витрат учасників грошового обороту; курс національної грошової одиниці [6, с. 47].

Під об'єктами державного регулювання монетарних процесів, на наш погляд, доцільно розуміти, не тільки бульбашки цін на активи, що відбивається на волатильності фінансових ринків, а й стабільність і взаємозв'язок учасників фінансових ринків. 
Таким чином, об'єктами державного регулювання монетарних процесів $є$ попит на гроші та їх пропозиція, обсяг і структура грошової маси, що знаходиться в обігу; швидкість обігу грошей; обсяг кредитів, наданих економіці; коефіцієнти грошової мультиплікації; обсяг і структура грошових доходів та витрат учасників грошового обороту; курс національної грошової одиниці, коливання фінансових ринків, стабільність і взаємозв'язок учасників фінансових ринків.

При цьому, на наш погляд, бульбашки цін на активи, а, отже, коливання фінансових ринків, а також стабільність і взаємозв'язки учасників фінансових ринків слід розглядати як об'єкти такого елемента державного регулювання монетарних процесів, як регулювання фінансової стабільності, а не грошовокредитного і валютного регулювання. При такому підході розширення об'єктів державного регулювання не викликає конфліктів при включенні бульбашок цін на активи в об'єкти грошово-кредитного і валютного регулювання. Водночас їх слід розглядати як об'єкти державного регулювання монетарних процесів 3 огляду на те, що вони є об'єктами регулювання фінансової стабільності.

Суб'єктами державного регулювання монетарних процесів $є$, перш за все, центральний банк, як головний провідник монетарної політики, а також Міністерство фінансів та інші органи, які своїми рішеннями і діями можуть вплинути на фінансову сферу, а в його структурі на грошово-кредитну і валютну сфери. Основні питання, що стосуються суб'єктів регулювання монетарних процесів, були спрямовані на незалежність центральних банків, що обумовлено тим, що при наданні впливу з боку урядів на центральні банки, з'являється велика ймовірність переслідування короткострокових цілей, що конфліктують 3 довгостроковими [7, с. 43].

Тим часом, криза поставила в центр обговорень також і питання про створення нових органів з підтримки фінансової стабільності на макрорівні. Як результат багато країн стали визначати забезпечення фінансової стабільності як функцію певних органів: центральних банків, міністерств фінансів або нових органів, відповідальних за макропруденційне регулювання.

3 огляду на те, що державне регулювання монетарних процесів передбачає не тільки грошово-кредитне i валютне, а й макропруденційне регулювання, органи із забезпечення фінансової стабільності також є суб'єктами державного регулювання монетарних процесів, як і суб'єкти грошово-кредитного і валютного регулювання. Таким чином, суб'єктами державного регулювання монетарних процесів $\epsilon$ монетарна влада, в особі центральних банків та інших державних органів, що впливають на грошово-кредитну і валютну сфери, а також органи, що регулюють фінансову стабільність.

Під інструментами державного регулювання монетарних процесів розглядаються способи, за допомогою яких монетарна влада впливає на економічні процеси, в тому числі монетарні. При цьому у своїй діяльності монетарна влада використовує сукупність інструментів грошово-кредитного 
регулювання і регулювання фінансової стабільності.

До глобальної фінансово-економічної кризи більшість монетарної влади у своїй діяльності користувалися трьома основними або традиційними інструментами грошово-кредитного та валютного регулювання: операції на відкритому ринку, обов'язкові резервні вимоги та операції постійної дії. Однак у кризових умовах ці інструменти перестали працювати головним чином через дві причини. По-перше, фінансова система перестала виконувати свою основну функцію - спрямування фінансових коштів людям і організаціям $з$ ефективними інвестиційними можливостями, що призводить до шоків в економіці. По-друге, за умов надзвичайно низьких процентних ставок, центральні банки не могли знижувати їх далі з метою підтримки економіки.

Вищеназвані фактори послужили причинами застосування нетрадиційних інструментів грошово-кредитного і валютного регулювання, не заснованих на процентних ставках, які дозволили монетарній владі при нульових процентних ставках стимулювати економіку. На думку П. Куцик та О Ковтун, в посткризових умовах, коли такі макроекономічні показники як зростання ВВП, рівень інфляції, стабільність валютних ринків, а також платіжний баланс знаходяться на прийнятному рівні, рівень безробіття все ще залишався дуже високим, що послужило головною причиною використання нетрадиційних інструментів [7, с. 21].

Тим часом, в економічній літературі ще неясним залишається питання щодо того, чи достатньо традиційне грошово-кредитне і валютне регулювання через процентні ставки при низьких процентних ставках і близькою до нуля інфляції.

На думку прихильників застосування нетрадиційних інструментів, у державному регулюванні монетарних процесів у нинішній економіці, їх використання призводить до залучення більшої кількості учасників до фінансового ринку, тим самим сприяючи кращому трансмісійному механізму. Інші економісти, які також підтримують даний підхід, підкреслюють, що нетрадиційні інструменти дозволяють створити великі короткострокові безпечні активи, сприяючи підвищенню фінансової стабільності [8, с. 166].

Крім того, нетрадиційні інструменти монетарної політики можуть бути застосовані і надалі, тому що причиною їх появи послужило структурні зміни, що відбулися на фінансових ринках. До таких змін економіст відносить зрослу роль операцій забезпеченого грошового ринку; набуття важливості не тільки ставки овернайт, а й широкого набору інших ринкових ставок; зростаючу актуальність небанківських установ у ринкових фінансах; i, нарешті, брак безпечних активів, які впливають на функціонування ринків і управління заставою [9, с. 10].

Розглянуті інструменти грошово-кредитного та валютного регулювання застосовуються 3 метою забезпечення цінової стабільності. Однак, під інструментами, застосовуваними в державному регулюванні монетарних процесів, доцільно також розглядати інструменти, що застосовуються $з$ метою забезпечення фінансової стабільності.

Механізм, через який монетарна політика впливає на процеси в економіці, 
називається трансмісійним механізмом. При цьому такий вплив здійснюється через різні канали трансмісійного механізму, такі як: процентний, кредитний (у тому числі канал балансу позичальника, канал банківського кредитування і канал банківського капіталу), валютний, інфляційних очікувань, цін активів або балансовий, витрат, прийняття ризику, добробуту, якісних i кількісних послаблень.

В умовах сучасної економіки, коли фінансова стабільність стала розглядатися як одна з необхідних умов, що забезпечують зростання економіки поряд зі стабільністю цін, в економічній літературі активно обговорюються механізми впливу каналів цін активів, витрат, прийняття ризику, якісних i кількісних послаблень. Однак, в українській економіці визнаються ключовими процентний, кредитний, валютний канали i канал інфляційних очікувань, a найбільш значущим - процентний канал. Вплив інших каналів в українській економіці оцінюється як незначний.

Тим часом, на наш погляд, 3 огляду на те, що фінансова стабільність має значний вплив на економічні процеси, необхідно розглядати вплив макропруденційного регулювання, ㄲi цілей та інструментів як на грошовокредитне регулювання, так і на економіку в цілому.

У своій діяльності з регулювання монетарних процесів, у тому числі при грошово-кредитному і валютному регулюванні монетарна влада діє відповідно до «політики за правилами», «дискреційної політики» або на основі їх сукупності.

У науковій літературі найбільш відомими правилами є правила Вікселя, Ірвінга Фішера, Фрідмена, таргетування номінального доходу або ВВП, МакКаллума, Гудхарта, Тейлора, Хендерсона-Маккіббіна, Болла, Банку Англії, банку Норвегії, на базі інфляційного прогнозу, індексу монетарної кон'юнктури і т. д.

Однак перераховані вище правила монетарної політики, на основі яких проводиться грошово-кредитне і валютне регулювання, не охоплюють всі фактори складного економічного середовища і не розглядають застосування нетрадиційних інструментів, що також $є$ причиною проблематичності проведення «політики за правилами». У той же час їх використання дозволяє аналізувати вплив на економіку різних рівнів процентних ставок, тим самим будучи хорошим доповненням до рішень монетарної влади. Зокрема, дослідження показують, що в умовах низьких процентних ставок не можна покладатися на правила монетарної політики, i треба застосовувати нетрадиційні інструменти, а коли рівноважна реальна процентна ставка піднімається вище 1, то правила можуть працювати [9, с. 178].

Дослідження переваг i недоліків регулювання на основі «політики за правилами» $\mathrm{i}$ «дискреційної політики» показує, що:

- «політика за правилами» дозволяє визначити план дій, якого монетарна влада повинна дотримуватися, в той час як «дискреційна політика» дає можливість частого реагування на економічні показники на свій розсуд;

- хоча «політика за правилами» критикується за жорсткість, вона забезпечує 
визначеність і ясність в тому, що монетарна влада не пожертвує довгостроковими цілями заради короткострокових;

- «дискреційна політика» надає можливість гнучкого реагування на складні економічні процеси, однак суб'єктивні знання і мотиви можуть перешкоджати ефективній політиці;

- бюрократія, яким $\epsilon$ центральний банк-головний провідник монетарної політики, не вміє обробляти нові інформації і вносити відповідні зміни в політику [10, с. 25].

Тим часом, в сучасній економіці регулювання монетарних процесів, засноване на застосуванні сукупності цих правил, стає все популярнішим серед економістів. Поєднання двох, здавалося б, суперечливих підходів дозволяє враховувати при регулюванні монетарних процесів такі фактори, як враження або страх, яких складно привести до кількісних значень, тим самим нівелюючи негативні наслідки від застосування того чи іншого одного виду політики.

Крім того, на наш погляд, поєднання «політики за правилами» i «дискреційної політики» сприяє отриманню більшого ефекту від державного регулювання монетарних процесів 3 огляду на те, що дозволяє поєднувати грошово-кредитне регулювання і регулювання фінансової стабільності.

3 одного боку, існуючі правила стосуються тільки грошово-кредитного та валютного регулювання, але не фінансової стабільності. 3 іншого боку, ще не розроблено правило, яке враховувало б вплив фінансової стабільності або взаємозв'язок монетарної та макропруденційної політик. У зв'язку 3 чим, регулювання фінансової стабільності проводиться за «дискреційною політикою». Отже, регулювання монетарних процесів, що вимагає регулювання і грошовокредитної і валютної сфери, і фінансової стабільності, необхідно проводити на основі сукупності «політики за правилами» і «дискреційної політики».

Висновки. Таким чином, дослідження методологічних засад державного регулювання монетарних процесів у сучасній економіці показує, що світова фінансово-економічна криза значною мірою піддала критиці і перегляду основні питання регулювання монетарних процесів, у тому числі, його цілі, об'єкти i суб'єкти, інструменти, трансмісійний механізм, а також правила. У зв'язку з цим нам видається важливим аналізувати i розвивати регулювання монетарних процесів в сучасній економіці. Але перед цим слід розглянути особливості забезпечення фінансової стабільності для більш повного дослідження державного регулювання монетарних процесів у сучасній економіці.

\section{Лimepamypa:}

1. Азарян О. М., Шепелев О. О. Прогнозування та макроекономічне планування в системі державного управління національною економікою: теорія і практика: монографія / під ред. д-ра екон. наук., проф. О. О. Шубіна. Донецьк [б.в.], 2010. 148 с.

2. Федишин М.П., Солійчук А.О. Макропруденційна політика нбу як інструмент посилення фінансової стабільності. Часопис економічних досліджень. 2021. №1 (1). С. 10-23.

3. Гудіма Т. С. Господарсько-правове забезпечення реалізації грошово-кредитної політики 
держави на засадах сталого розвитку: монографія. Київ: ДУ «Јнститут економіко-правових досліджень імені В. К. Мамутова Національної академії наук України», 2020. 336 с.

4. Державне фінансове регулювання економічних перетворень: монографія / I.Я. Чугунов, А.В. Павелко, Т.В. Канєва, та ін. ; за заг. ред. А.А. Мазаракі. Київ: Київ. нац. торг.-екон. ун-т, 2015. 376 с.

5. Єфименко T. I. Фіскальна та монетарна безпека національної економіки: монографія. Київ: ДННУ “Академія фінансового управління”, 2016. 447 с.

6. Козюк В.В. Монетарні засади глобальної фінансової стабільності: монографія. Тернопіль: ТНЕУ, “Економічна думка”, 2009. 728c.

7. Куцик П. О. Ковтун О. І., Башнянин Г. І. Глобальна економіка: принципи становлення, функціонування, регулювання та розвитку: монографія. Львів: Видавництво ЛКА, 2015. 594 с.

8. Малий I., Радіонова I., Смельяненко Л. Антикризове управління національною економікою: монографія / за заг. ред. І. Малого. Київ: КНЕУ, 2017. 368 с.

9. Модернізація економіки промислових регіонів України в умовах децентралізації управління: монография / O.І. Амоша, Ю.М. Харазішвілі, В.І. Ляшенко та ін. / НАН України, Ін-т економіки пром-сті. Київ, 2018. 300 с.

10.Подік І.І., Гончаров Ю.В. Податкова складова економічної безпеки України: монографія. Київ:Інтерсервіс, 2017. 210 с.

\section{References:}

1. Azarian, O. M., Shepelev ,O. O. (2010). Prohnozuvannia ta makroekonomichne planuvannia v systemi derzhavnoho upravlinnia natsionalnoiu ekonomikoiu: teoriia i praktyka [Forecasting and macroeconomic planning in the system of public administration of the national economy: theory and practice]. Donetsk: b.v. [in Ukrainian].

2. Fedyshyn, M.P., Soliichuk, A.O. (2021). Makroprudentsiina polityka nbu yak instrument posylennia finansovoi stabilnosti [NBU macroprudential policy as a tool to strengthen financial stability]. Chasopys ekonomichnykh doslidzhen - Journal of Economic Research. 1 (1). 10-23. [in Ukrainian].

3. Hudima, T. S. (2020). Hospodarsko-pravove zabezpechennia realizatsii hroshovo-kredytnoi polityky derzhavy na zasadakh staloho rozvytku [Economic and legal support for the implementation of monetary policy of the state on the basis of sustainable development]. Kyiv: DU «Instytut ekonomiko-pravovykh doslidzhen imeni V. K. Mamutova Natsionalnoi akademii nauk Ukrainy». [in Ukrainian].

4. Chuhunov, I.Ia., Pavelko, A.V., Kanieva, T.V., Mazaraki, A.A. (2015). Derzhavne finansove rehuliuvannia ekonomichnykh peretvoren. [State financial regulation of economic transformations]. Kyiv: Kyiv. nats. torh.-ekon. un-t. [in Ukrainian].

5. Iefymenko, T. I. (2016). Fiskalna ta monetarna bezpeka natsionalnoi ekonomiky [Fiscal and monetary security of the national econom]. Kyiv: DNNU "Akademiia finansovoho upravlinnia" [in Ukrainian].

6. Koziuk, V.V. (2009). Monetarni zasady hlobalnoi finansovoi stabilnosti [Monetary principles of global financial stability]. Ternopil: TNEU, "Ekonomichna dumka". [in Ukrainian].

7. Kutsyk, P. O. Kovtun ,O. I., Bashnianyn, H. I. (2015). Hlobalna ekonomika: pryntsypy stanovlennia, funktsionuvannia, rehuliuvannia ta rozvytku [Global economy: principles of formation, functioning, regulation and development]. Lviv: Vydavnytstvo LKA. [in Ukrainian].

8. Malyi, I., Radionova, I., Yemelianenko, L. (2017). Antykryzove upravlinnia natsionalnoiu ekonomikoiu [Anti-crisis management of the national economy]. Kyiv: KNEU. [in Ukrainian].

9. Amosha, O.I., Kharazishvili, Yu.M., Liashenko, V.I. (2018). Modernizatsiia ekonomiky promyslovykh rehioniv Ukrainy $\mathrm{v}$ umovakh detsentralizatsii upravlinnia [Modernization of the economy of industrial regions of Ukraine in terms of decentralization of management]. Kyiv: NAN Ukrainy, In-t ekonomiky prom-sti. [in Ukrainian].

10. Podik, I.I., Honcharov, Yu.V. (2017). Podatkova skladova ekonomichnoi bezpeky Ukrainy. [Tax component of economic security of Ukraine]. Kyiv:Interservis. [in Ukrainian]. 